soil samples were collected in order to: (1) find a regolith with economic contents of these elements, and (2) to trace apatite and pyrochlore-rich søvite dykes under the soil.

Acknowledgements. The field work was supported by the European Economic Community through contract number MSM-119-DK.

\title{
References
}

Brögger, W. C. 1921: Die Eruptivgesteine des Kristianiagebietes IV, Das Feugebiet in Telemarken, Norwegen. Norske Vidensk. Selsk. I, Mat. Nat. Skr. Kl. 7, 408 pp.

Gothenborg, J., Keto, L \& Pedersen, J. L., 1977: Exploration of the Qaqarssuk carbonatite complex, 1976. Kryolitselskabet Øresund A/S. Unpubl. company report.

Kunzendorf, H. \& Secher, K. in press: Dispersion of niobium and phosphorus in soil overlying the Qaqarssuk carbonatite complex, southern West Greenland. J. geochem. Explor.

Larsen, L. M., Rex, D. C. \& Secher, K. 1983: The age of carbonatites, kimberlites and lamprophyres from southern West Greenland: recurrent alkaline magmatism during 2500 million years. Lithos 16, 215-221.

Secher, K. 1980: Distribution of radioactive mineralisation in central West Greenland. Rapp. Grønlands geol. Unders. 100, 61-65.

Vuotovesi, T. 1974: [Qaqarssuk carbonatite complex.] Univ. Helsinki. Unpubl. M.Sc. thesis, 44 pp. [in Finnish].

\section{Shallow-seismic, geoelectric and magnetic investigations of the Qaqarssuk carbonatite complex, West Greenland}

\author{
Morten Kjærgaard and Kim B. Olsen
}

During the period 3rd July to 3rd September 1984 geophysical measurements were made in the Qaqarssuk area. The investigations focussed on:

(1) Shallow-seismic and geoelectric investigations of the overburden, especially its thickness.

(2) Magnetic measurements in order to refine the modelling based on existing data from Kryolitselskabet Øresund A/S (Kurki \& Juhava, 1971; Gothenborg \& Pedersen, 1976).

\section{Mapping of the overburden}

The aim of the geoelectric and seismic measurements was primarily to map the thickness of the overburden in areas where a cover of weathered rock (regolith) was expected (Knudsen, this report). On the basis of drillhole measurements in the central valley (area 1 on fig. 13), the thickness of the overburden was estimated to be about $5 \mathrm{~m}$ (Knudsen \& Secher, 1984).

The investigations were carried out mainly in two areas (fig. 13). 


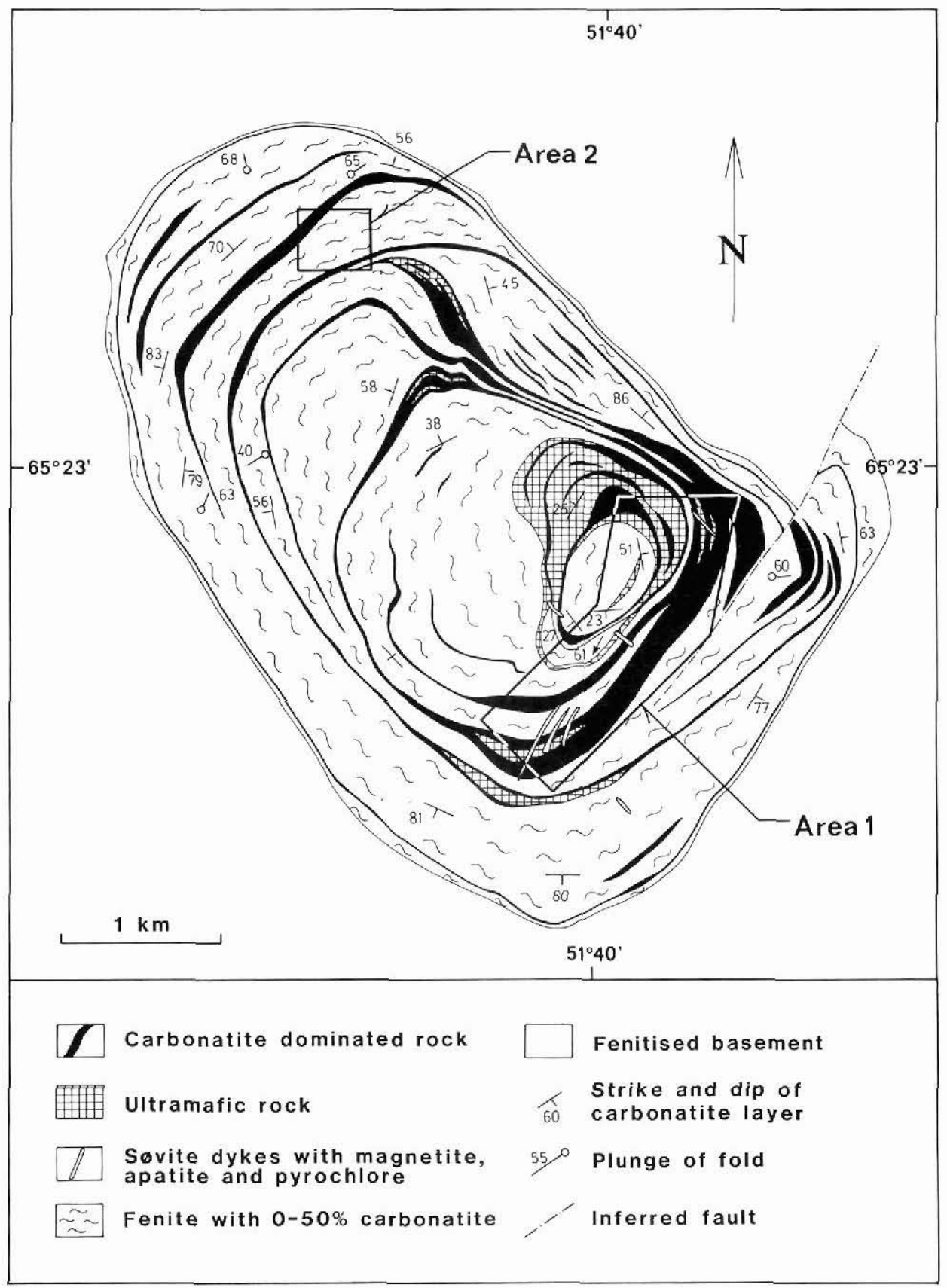

Fig. 13. Situation map of the two areas of geophysical investigation. After Knudsen, this report. 


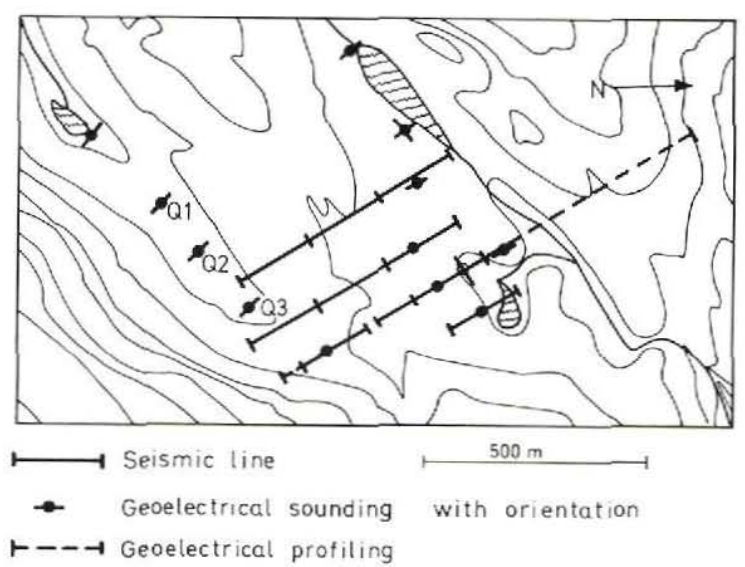

Fig. 14. Sketch map of the seismic and geoelectric lines in the northern area (area 2).

\section{Seismic investigations}

The seismic equipment included a 12 channel OYO McSeis 1500 enhance and display unit, and 12 single geophones. Both hammer and explosives (Dynamex B) were used as energy sources. Power supply was delivered from a $12 \mathrm{~V}$ accumulator.

When the hammer was used as the energy source, it was necessary to strake the signal several times, often as many as $20-30$ times. Surprisingly, this did not seem to improve the signal/noise ratio significantly. Therefore explosives which gave a much better signal were normally used as the energy source. Usually charges of 100-200 g were sufficient to penetrate the overburden. The firing was mostly done in water, but where this was impossible the charge was buried under $0.5-1 \mathrm{~m}$ soil, or covered with a 10-20 1 waterbag.

Nine shots were carried out in the northern area (fig. 14) and 43 in the southern area. The profiles were predominantly oriented perpendicular to the strike. Geophone spacings varied between 2 and $15 \mathrm{~m}$ depending on the expected thickness of the overburden. Usually reversed shots were made, but to save time, some profiles (especially in the northern area) were only shot from one end.

Two or three layers could usually be distinguished from the seismograms. The top layer, with a velocity of $300-1500 \mathrm{~m} / \mathrm{s}$, may consist of fluvial sediments and soil. The thickness never exceeds $8 \mathrm{~m}$. The intermediate layer with a velocity of $1800-3000 \mathrm{~m} / \mathrm{s}$ can reach a probable thickness of $25 \mathrm{~m}$. This layer may consist of weathered rock or regolith (Knudsen, this report). The third layer, with a velocity of $4000-7300 \mathrm{~m} / \mathrm{s}$, is obviously the hard rock. The two top layers are difficult to map because of their varying thicknesses with one or both layers missing in some places. The velocities fit very well with velocities measured in similar layers in the Sokli carbonatite complex, Finland (Paarma et al., 1981).

Apart from the refraction investigations of the thickness of the overburden, a few shots, using charges of $1.0-3.3 \mathrm{~kg}$, were fired to detect a possible reflection from the top of the magma chamber. However, no deep reflectors were observed. 


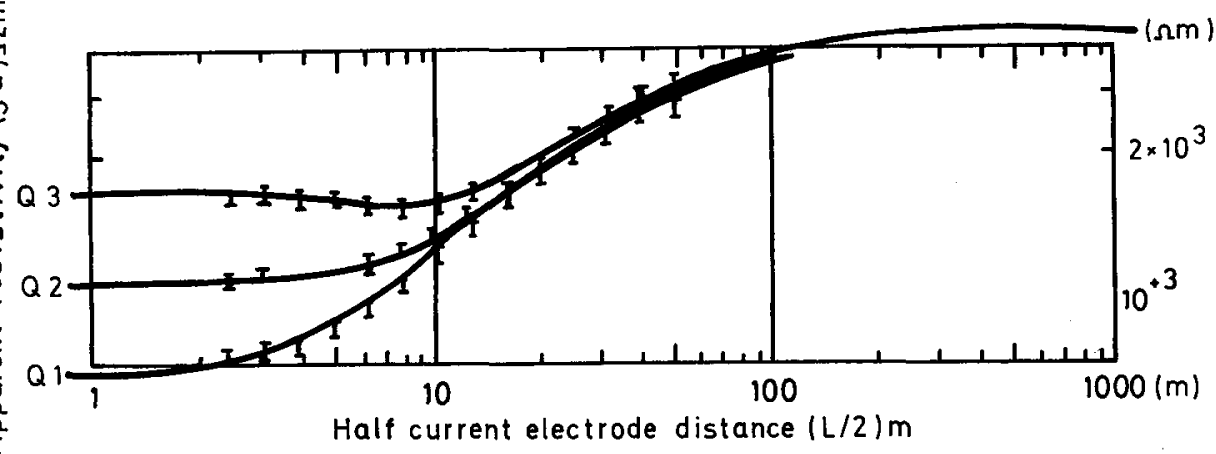

Fig. 15. Geoelectric Schlumberger sounding curves showing the influence of water saturation on the apparent resistivity. Note the increasing water saturation from Q1 to Q3.

\section{Geoelectrical investigations}

The geoelectrical equipment included an ABEM SAS 300 terrameter, an SAS 200 booster, two $400 \mathrm{~m}$ sounding cables and two Wenner-cables for fixed spread measurements (electrode spacings $20 \mathrm{~m}$ and $10 \mathrm{~m}$, respectively).

A total of 15 soundings were carried out in the northern area, (fig. 14) and 17 in the southern area. In an attempt to make a three-dimensional model the profiles were generally placed perpendicular to the dominant strike, and in a few places parallel to the strike.

In order to determine the characteristic resistivity of the local rocks some of the first soundings were made in the areas where exposures indicated homogenous hard rock. These soundings indicated a resistivity for fenite of 4000-12000 $\Omega \mathrm{m}$ and a resistivity for carbonatite of about $3000 \Omega \mathrm{m}$. All resistivities, especially in the carbonatite, varied greatly, depending on the water saturation, mineral composition and topography. It is also known that permafrost is of great influence on the resistivity (Klitten \& Olesen, 1972).

The influence of water saturation on the apparent resitivity is shown in fig. 15. The three measurements were carried out in a minor depression in the northern valley (fig. 14) spaced 100-200 m apart. The water saturation decreased gradually from $\mathrm{Q} 1$, in an area with a very high water saturation, to $\mathrm{Q} 2$ and $\mathrm{Q} 3$. The three measurements indicate a cover of 3-8 $\mathrm{m}$ resting upon the hard rock and having a resistivity of $6000 \Omega \mathrm{m}$ - presumably fenite.

Generally, the sounding curves may be interpreted with two to four layer models with overburden resistivities in the range 100-2000 $\Omega \mathrm{m}$, and hard rock resistivities in the range 2000-6000 $\Omega \mathrm{m}$. The thickness of the overburden is normally 5-15 m. If one compares the soundings with shallow seismics, it is evident that the soundings give more detailed information on the differentiation in the top soil and the weathered hard rock, than was obtained by the seismic measurements.

The electrical profiles across the area were aimed at mapping near surface structures such as faults and joints. A length of $3.3 \mathrm{~km}$ was mapped with a Wenner configuration with electrode spacing of $20 \mathrm{~m}$, and a length of $3.2 \mathrm{~km}$ (partly overlapping) was mapped with an electrode spacing of $10 \mathrm{~m}$.

The measurements with short electrode spacing generally showed much more resistivity variation than the measurements with greater spacing. However, it is difficult to distinguish 
between the effects of topography, water saturation, permafrost, the variation in mineralogy, and faults and joints.

\section{Magnetic measurements}

The measurements were made by means of a hand-held kappameter (Geofyzika Brno, kT-5) ranging between $10^{-5}$ and $1 \mathrm{SI}$.

Susceptibility measurements were made at several sites, and on different rock types in the area. A total of about $\mathbf{5 0 0}$ measurements were made.

The general feature found was that the fenite has susceptibilities in the range 0.1 to $1 \times$ $10^{-3} \mathrm{SI}$, and the ultramafite about 0.5 to $40 \times 10^{-3} \mathrm{SI}$. The susceptibility values of the carbonatite vary widely from $1 \times 10^{-3} \mathrm{SI}$ up to more than $1000 \times 10^{-3} \mathrm{SI}$. This includes occasional off-scale measurements (over $1000 \times 10^{-3} \mathrm{SI}$ ). Values obtained in a single carbonatite layer could vary between one and two orders of magnitude within a few centimetres due to the variation in the magnetite content. Magnetically the carbonatite is thus very inhomogeneous on a mesoscopic scale.

In all, 18 oriented specimens were collected for later palaeomagnetic measurements in the laboratory.

\section{Conclusions}

Both geoelectric and seismic methods were found to be useful in the investigations of the overburden. Because the geoelectric method was the least time-consuming and appears to supply more detailed information on the overburden, the method is probably the most suitable for this type of investigation.

The overburden thickness determined by the two methods correlate reasonably well. However, further calculations are necessary before an overburden map can be constructed from the available data.

\section{References}

Gothenborg, J. \& Pedersen, J. L. 1976: Exploration of the Qaqarssuk carbonatite complex, 1975, part II. Kryolitselskabet Øresund A/S. Unpubl. company rep.

Klitten, K. \& Olesen, O. B. 1972: Geoelektriske resistivitetsmålinger ved permafrostunders $\emptyset$ gelser i Holsteinsborg, Grønland. Rapp Grønlands geol. Unders. 47, 24 pp.

Knudsen, C. \& Secher, K. 1984: Apatite mineralisation in carbonatite and ultramafic intrusions in Greenland. Interim report 1. Unpubl. intern. GGU rep., 24 pp.

Kurki, J. \& Juhava, R. 1971: Report on the exploration in Søndre Isortoq area, 1970. Kryolitselskabet $\emptyset$ resund A/S. Unpubl. company rep.

Paarma, H., Vartiainen, H., Litvinenko, V. I. \& Muzylev, V. V. 1981: Geological interpretation of seismic soundings at the Sokli carbonatite complex, northern Finland. In Puustinen, K. (edit.) Geological, geochemical and geophysical investigations in eastern part of the Baltic Shield. Papers issued to the 10th General Meeting of the Finish-Soviet Joint Geological Working Group, held in Rovaniemi, 1981, 213-224.

Laboratoriet for Geofysik, Aarhus Universitet, Finlandsgade 6-8, DK-8200 Arhus N. 